\title{
Biological sulphate reduction with primary sewage sludge in an upflow anaerobic sludge bed (UASB) reactor - Part 4: Bed settling characteristics
}

\author{
J Poinapen, GA Ekama* and MC Wentzel \\ ${ }^{1}$ Water Research Group, Dept. of Civil Engineering, University of Cape Town, Rondebosch 7701, South Africa
}

\begin{abstract}
The success of the UASB reactor depends largely on the settling properties and stability of the sludge bed which comprises the anaerobic active biomass. The solid-liquid separation behaviour of the sludge bed in 2 UASB reactors $\left(\mathrm{R} 1\right.$ at $35^{\circ} \mathrm{C}$ and $\mathrm{R} 2$ at $20^{\circ} \mathrm{C}$ ) fed with primary sewage sludge and sulphate was investigated because this appeared to be a retention timedefining feature of the system. Consequently, the settling rate of the various solids fractions in the sludge was measured in a settleometer to determine if bed expansion or sludge settleability was the capacity-limiting process. It was found that both sludges settled well and at an upflow velocity of up to $1.16 \mathrm{~m} / \mathrm{h} 99 \%$ of the total sludge mass was retained. This upflow velocity was 9.1 and 13.7 times higher than the maximum operating upflow velocity of UASB reactors R1 $(0.127 \mathrm{~m} / \mathrm{h})$ and R2 $(0.085 \mathrm{~m} / \mathrm{h})$ respectively that caused system failure. Tests were also done to demonstrate the effect of upflow velocity $\left(\mathrm{V}_{\text {wp }}\right)$ on the sludge bed expansion. Relative to the settled sludge volume at zero upflow, the R1 sludge expanded 1.8 times at a $\mathrm{V}_{\text {up }}$ of $0.127 \mathrm{~m} / \mathrm{h}$ while $\mathrm{R} 2$ sludge expanded 2.0 times at a $\mathrm{V}_{\text {up }} 0.085 \mathrm{~m} / \mathrm{h}$. From the tests, $\mathrm{R} 1\left(35^{\circ} \mathrm{C}\right)$ sludge had a better settleability and expanded less compared to $\mathrm{R} 2\left(20^{\circ} \mathrm{C}\right)$ sludge for the same applied upflow velocity. Because in operating $\mathrm{R} 1$ and R2, the bed volume was kept constant, the mass of sludge removed from the system correspondingly increased as upflow increased and the bed expanded, causing a reduced sludge age and sludge bed mass to mediate the bioprocesses. It was concluded that the system failure was caused by bed expansion rather than by the sludge settleability.
\end{abstract}

Keywords: biological sulphate reduction, upflow unaerobic sludge bed reactor, sludge settleability, bed expansion

\section{Nomenclature}

\section{BER bed expansion ratio}

BSR biological sulphate reduction

COD chemical oxygen demand

Dia diameter

HAc acetic acid

HRT hydraulic retention time

ID inside diameter

OD outside diameter

PSS primary sewage sludge

PVC polyvinylchloride

Q hydraulic flow

R1 UASB Reactor 1

R2 UASB Reactor 2

TSS total suspended solids

UASB upflow anaerobic sludge bed reactor

VFA volatile fatty acids

$\mathrm{V}_{\text {up }} \quad$ upflow velocity

\section{Introduction}

The application of the upflow anaerobic sludge bed (UASB) reactor in high-rate anaerobic wastewater treatment systems (mainly from industrial sources) has gained considerable attention over the past 3 decades. The success of the UASB reactor

\footnotetext{
* To whom all correspondence should be addressed.

III. +2721 650 2585; fax: +27216897471 ; e-mail: George.Ekama@uct.ac.za

Received 13 January 2009; accepted in revised form 31 July 2009.
}

depends largely on the settling properties and stability of the sludge bed which contains the active biomass. A stable sludge bed provides a long sludge retention time and a high sludge mass, and these are key features to ensure process stability and high substrate loading rates, thereby maximising the UASB system performance.

From the operation of 2 lab-scale UASB reactors (R1 and $\mathrm{R} 2$ operated at $35^{\circ} \mathrm{C}$ and $20^{\circ} \mathrm{C}$ respectively) fed sulphate and PSS, the HRT was decreased (by increasing the feed flow rate) to determine the minimum HRT (giving the smallest reactor volume) at which the effluent meets the quality criteria (i.e. $\mathrm{SO}_{4}^{2-}$ $<250 \mathrm{mgSO}_{4}^{2-/ \ell}$ and VFA $<100 \mathrm{mgHAc} / \ell$ ) (Poinapen et al., 2009). For instance, reactor R1 had a minimum HRT of $13.5 \mathrm{~h}$ when fed $1500 \mathrm{mgSO}_{4}^{2-/ \ell}$. A further reduction in HRT $(<13 \mathrm{~h})$ resulted in unstable bed conditions and progressive system failure, indicated by poor effluent quality, that is, high effluent VFA, $\mathrm{SO}_{4}^{2-}$ and particulate COD. This prompted an investigation into the solid-liquid separation behaviour of the sludge bed because this appeared to be a retention time-defining feature of the system. Consequently, the settling rate of the various solids fractions in the sludge was measured to determine whether bed expansion or sludge settleability was the capacity-limiting process.

Accordingly, a sludge settleability device, called a settleometer, was built and operated to test the 2 UASB sulphidogenic sludges (R1 and R2 sludges) at different flow through rates. This settleometer was designed based on the method developed by Moosbrugger (1994).

\section{Materials and methods}

A series of 4 vertical transparent PVC columns of outer diameters (OD) 63, 75, 90 and $110 \mathrm{~mm}$ and internal diameters (ID) 


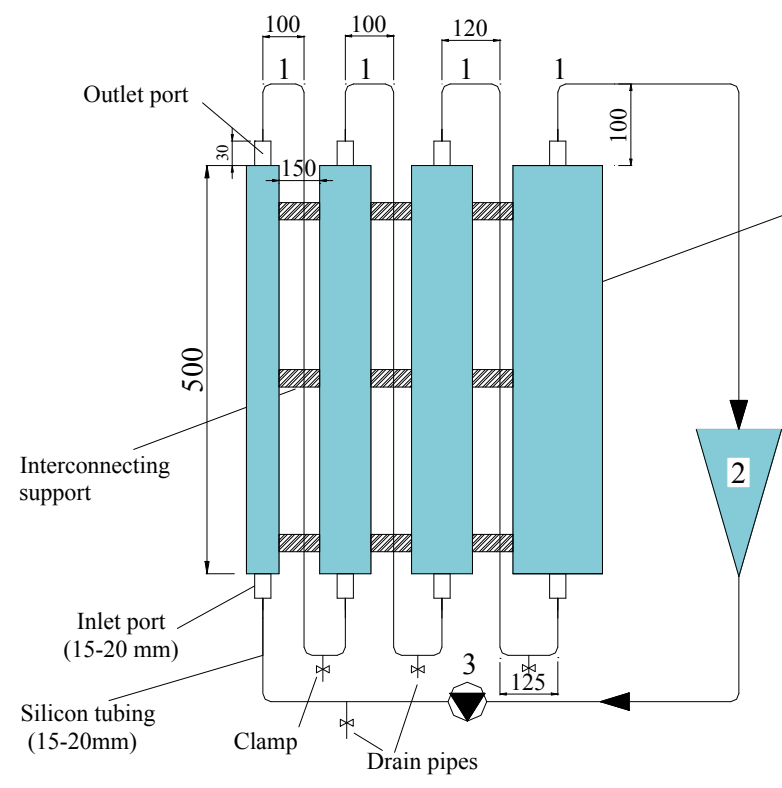

Transparent PVC tubes Outside Diameter $(\mathrm{mm})$ : $63,75,90,110$

Internal Area $\left(\mathrm{mm}^{2}\right)$ : $2553,3612,5865,8762$

All dimensions are in $\mathrm{mm}$

(1) Interconnecting tubing (2) collection vessel and (3) pump

Figure 1

Schematic diagram of the settleometer

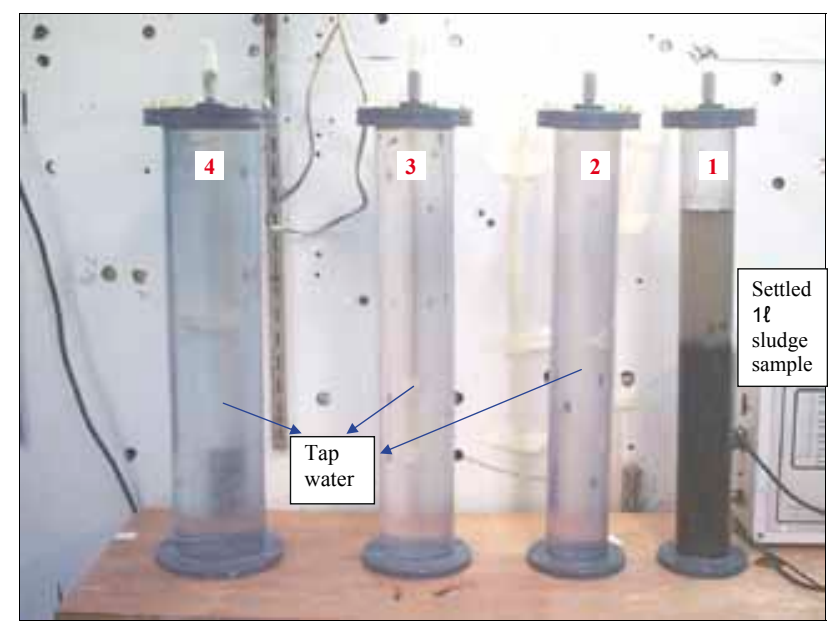

Figure 2

Picture of the settleometer with the 1 lab-scale UASB sludge after $5 \mathrm{~h}$ settling time before the application of flow rate

$57,67.8,86.4,105.6 \mathrm{~mm}$ respectively, was interconnected by plastic tubing ( $20 \mathrm{~mm}$ inner diameter). Each PVC column was $500 \mathrm{~mm}$ tall and was capped on both top and bottom ends with solid PVC lids with an outlet in the centre to attach the interconnecting plastic tubing. Stainless steel clamps were fitted to the bottom tubing for drainage. A collection vessel $(20 \ell)$ was connected to the last (largest) column (OD 110 $\mathrm{mm}$ ) which was then fitted to a peristaltic pump. The pump was in turn connected to the first (smallest) PVC column (OD $63 \mathrm{~mm}$ ) to close the water circuit. The $3^{\text {rd }}$ and $4^{\text {th }}$ columns were the ones representing the UASB column since their IDs were close to the UASB reactor ID $(93 \mathrm{~mm})$. A schematic flow diagram and a photograph of the settling device are shown in Figs. 1 and 2.

The principle of the settleometer is relatively simple: A predetermined volume (say $1 \ell$ ) of sludge is taken from a UASB reactor and placed in Column 1 (smallest). A constant flow rate
(Q) is applied in an upflow mode similar to the UASB reactor (Fig. 2). Since the upflow velocity $\left(\mathrm{V}_{\text {up }}\right)$ decreases incrementally in the subsequent columns (from smallest to largest), the sludge sample is fractionated according to particle size and density. The percentage sludge mass retained in each column is determined by dividing the mass of sludge retained in each column by the mass of sludge of the original sample. The sludge concentration in each column is determined by dividing the mass of sludge retained in each column by the initial sludge sample volume. Both the percentage sludge masses and the sludge concentrations are plotted against their respective upflow velocities, resulting in a graph describing the settling profile of the sludge at different hydraulic upflow velocities.

\section{Operating and testing procedures}

At the start of the experiment, it is necessary to fill the system with tap water and expel all air bubbles from the system - air bubbles, if not removed, impacts negatively on the results because they attach to sludge particles and create turbulence inside the columns when the pump is running. First, all 4 columns are filled to the top with tap water before closing with the top lids (Fig. 2). Then, tap water is added to the collection vessel and pumped through the system to fill all the interconnecting tubes and allow a smooth flow of water through the whole settleometer. This is necessary in order to expel all air bubbles. Each column interconnecting tube has at its uppermost section a tee-piece (normally clamped shut) from which air can be vented. When all the air bubbles have been expelled from the system, Column 1 (smallest) is emptied while the other 3 are left full. Then a UASB sludge sample is prepared in such a way that it represents the UASB reactor sludge bed and added carefully (to minimise sludge break-up) through a funnel to Column 1, ensuring that there are no air bubbles in the system before closing the column with its lid.

Both R1 and R2 sludges were tested separately in the settleometer. The entire sludge bed was drained from either R1 or R2 and gently mixed before a $1 \ell$ sample was collected. A further $50 \mathrm{~m} \ell$ sample was taken to measure its TSS concentration. Column 1, which had volume of $1.276 \ell$, was filled with the $1 \ell$ mixed sludge sample. Before starting the pump, the sludge was allowed to settle for a few hours (usually $5 \mathrm{~h}$ was sufficient) so as to imitate the same condition as the UASB reactor bed. The collection vessel was filled with slightly more than the remaining Column 1 volume $(>0.276 \ell)$ to prevent the pump from drawing air into the system. The peristaltic pump, pre-calibrated to the desired flow rate, was then switched on. The tee-piece on the interconnecting tube between Columns 1 and 2 was opened to vent all the air above the sludge sample. The flow rate was set such that more than $90 \%$ of the sludge mass was retained within the columns. Two different pre-determined pumping flow rates ( 7.08 and $10.17 \ell / \mathrm{h}$ respectively) were applied such that the upflow velocities in the last column (largest pipe) were 0.81 and $1.16 \mathrm{~m} / \mathrm{h}$ respectively. These upflow velocities were 6.4 and 9.1 times higher than the maximum 
upflow velocity $(0.127 \mathrm{~m} / \mathrm{h}$ ) at which the R1 system (when fed $\left.1500 \mathrm{mgSO}_{4}{ }^{2-/ \ell}\right)$ was operated to prevent failure. The same $\mathrm{V}_{\text {up }}$ values (i.e. 0.81 and $1.16 \mathrm{~m} / \mathrm{h}$ ) were applied to the R2 sludge sample and these were 9.5 and 13.7 times higher than the maximum upflow velocity $(0.085 \mathrm{~m} / \mathrm{h})$ at which the $\mathrm{R} 2$ system was operated to prevent failure - R2 was operated at a longer HRT than R1 (20.5 h against $13.5 \mathrm{~h}$ ) for the same feed sulphate concentration (1 $500 \mathrm{mgSO}_{4}^{2-/ \ell}$ ) due to the slower biological activity at the lower $\left(20^{\circ} \mathrm{C}\right)$ temperature.

The settleometer was run for $15 \mathrm{~h}$ to ensure steady state was established between the settling velocities of the sludge particles and the upflow velocities in the columns. At steady state, the expanded bed height in each column was measured. The pump was then switched off. The sludge fractions present in each column were then allowed to settle for 1 to $2 \mathrm{~h}$ and the bed height measured before drawing all the mixed liquor from the bottom of each column via its respective drain pipe (Fig. 3). The sludge fraction, collected from each column was then mixed thoroughly and a representative sample of $50 \mathrm{~m} \ell$ was taken and analysed for its TSS concentration. The TSS was measured using the same analytical procedure described in Standard Methods (1985). The mass of TSS (volume x concentration) in each column and in the collection vessel was calculated. This mass was compared with the initial sludge mass added to Column 1 to check the accuracy of the results. Better than $96 \%$ mass balances was achieved in the tests.

The R1 and R2 sludges were tested on two occasions on Day 540 and Day 545 . The first R1 and R2 tests were done at a flow rate of $7.08 \mathrm{l} / \mathrm{h}$ through the settleometer and the second at $10.17 \mathrm{\ell} / \mathrm{h}$. The expanded bed heights at steady were measured only in the second test after it was concluded from the first test that bed expansion was the reactor size-governing criterion. The results for R1 and R2 sludges are listed in Tables 1 and 2 respectively.

\section{Results}

\section{R1 sludge sample}

The sludge settleability profile depicted in Fig. 4 shows the $\%$ mass of TSS retained in each column vs. upflow velocity $(\mathrm{m} / \mathrm{h})$ of that column at the 2 different flow rates applied to the settleometer.

At $7.08 \mathrm{l} / \mathrm{h}, \sim 81 \%$ of the total sludge mass settled fast enough at a $\mathrm{V}_{\text {up }}$ as high as $2.8 \mathrm{~m} / \mathrm{h}$ to be retained in Column 1. At $\mathrm{Q}=10.17 \ell / \mathrm{h}$, only $30.5 \%$ was retained in Column 1 due to the higher $\mathrm{V}_{\text {up }}$ in the first column (smallest diameter, thus highest $\mathrm{V}_{\text {up }}$ ) and sludge transfer to the subsequent columns increased with $50 \%$ being retained in Column 2 . From the $10.17 \mathrm{\ell} / \mathrm{h}$ profile curve, it is observed that $\sim 80.5 \%(30.5 \%$ in Column 1 plus $50 \%$ in Column 2) of the total sludge mass settled fast enough at a $\mathrm{V}_{\text {up }}$ of $2.8 \mathrm{~m} / \mathrm{h}$ to be retained in Columns 1 and 2, which is the same as that retained in Column $1(81 \%)$ at $7.08 \mathrm{l} / \mathrm{h}$, giving confidence in the results obtained.

From the above, a cumulative sludge mass retained vs. settling velocity gives greater insight into the settling behaviour of the sludge (Table 1 and Fig. 5).

It can be seen from Table 1 (or Fig. 5) that more than $99 \%$ of the total sludge mass was retained in the settleometer at a $\mathrm{V}_{\text {up }}$ in Column 4 of $1.16 \mathrm{~m} / \mathrm{h}$ implying that almost all the solids in the sludge had a very good settleability. Since the maximum $\mathrm{V}_{\text {up }}$ at which R1 was operated was $0.127 \mathrm{~m} / \mathrm{h}$, it can be deduced that the cause for sludge bed instability when the reactor was operated at a $V_{\text {up }}>0.127 \mathrm{~m} / \mathrm{h}$ was not due to poor sludge settleability.

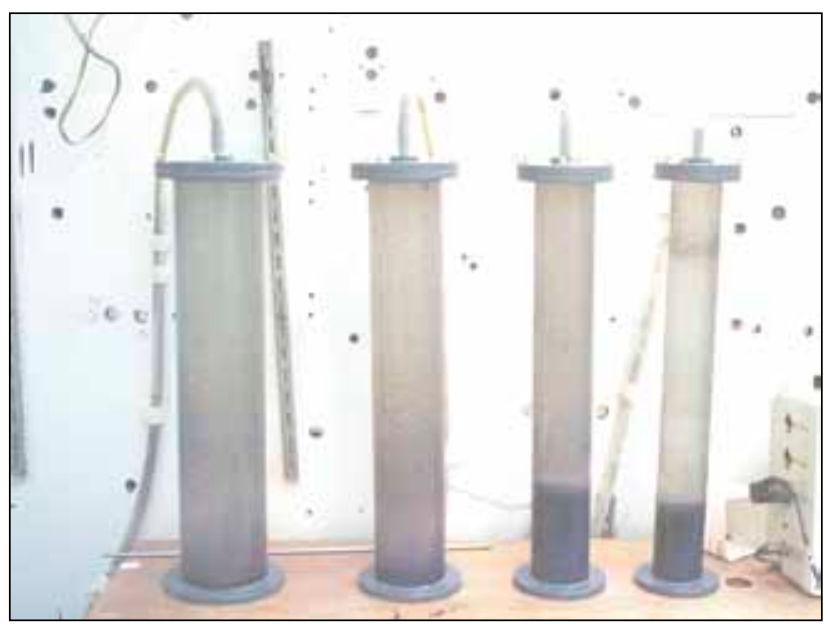

Figure 3

Picture of the settleometer showing $R 1$ sludge fraction retained in each column at steady state $\left(Q=10.17 \mathrm{l} / \mathrm{h}\right.$ and $V_{u p}=1.16 \mathrm{~m} / \mathrm{h}$ in the largest column)

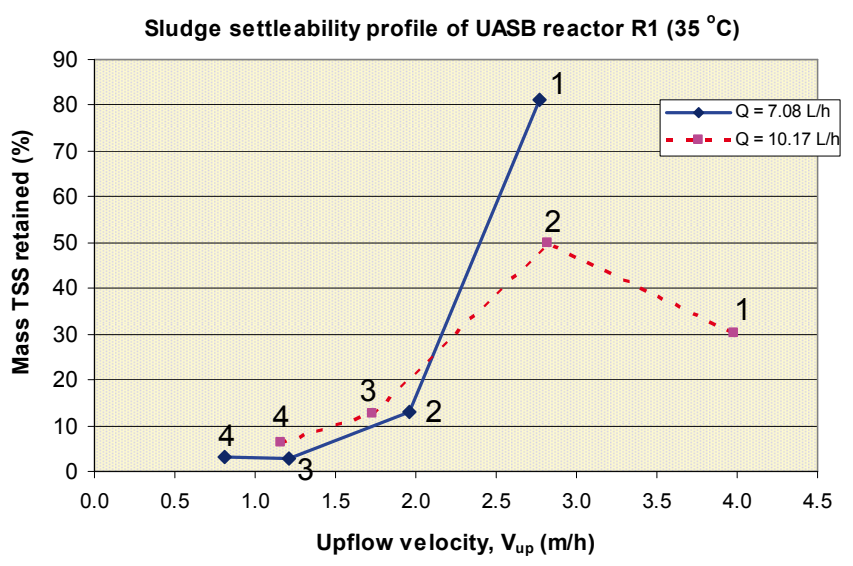

Figure 4

$R 1$ sludge settleability profile with respect to the 2 applied flow rates

Cumulative sludge mass retained in the settleometer (R1)

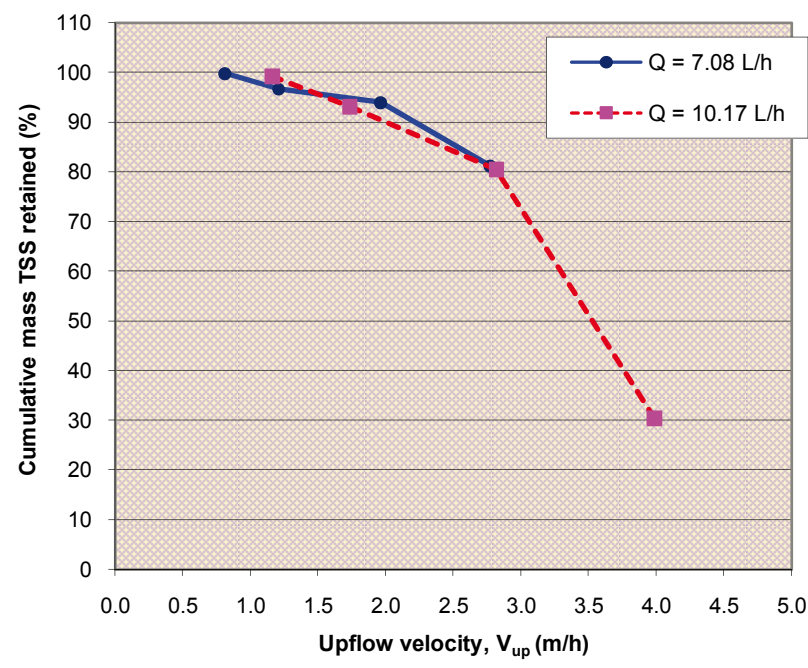

Figure 5

Percentage cumulative sludge mass retained with settling velocity (sludge from UASB reactor $R 1$ ) 


\begin{tabular}{|c|c|c|c|c|c|c|}
\hline \multicolumn{7}{|c|}{$\begin{array}{c}\text { TABLE } 1 \\
\text { Summary of results obtained with sludge from UASB reactor R1 }\end{array}$} \\
\hline \multicolumn{7}{|c|}{ R1 sludge } \\
\hline \multirow{6}{*}{$\begin{array}{l}\text { Applied flow rate, } \\
Q=7.08 \mathrm{e} / \mathrm{h}\end{array}$} & Column & $\begin{array}{l}\text { Dia. } \\
(\mathrm{mm})\end{array}$ & $\mathrm{V}_{\text {up }}(\mathrm{m} / \mathrm{h})$ & Mass TSS (g) & \% by Mass & $\begin{array}{l}\text { \% Retained } \\
\text { (Cumulative) }\end{array}$ \\
\hline & 1 & 63 & 2.77 & 28.71 & 81.06 & 81.06 \\
\hline & 2 & 75 & 1.96 & 4.55 & 12.85 & 93.91 \\
\hline & 3 & 90 & 1.21 & 0.96 & 2.70 & 96.61 \\
\hline & 4 & 110 & 0.81 & 1.12 & 3.17 & 99.78 \\
\hline & & Collection vessel & & 0.08 & 0.22 & \\
\hline \multicolumn{4}{|c|}{ Total mass recovered over the whole system $(\mathrm{g})$} & 35.41 & & \\
\hline \multicolumn{4}{|c|}{ Initial mass of the $1 \ell$ sludge sample $(\mathrm{g})$} & 36.71 & & \\
\hline \multicolumn{4}{|c|}{ Mass TSS recovered (\%) } & 96.5 & & \\
\hline \multirow{6}{*}{$\begin{array}{l}\text { Applied flow rate, } \\
Q=10.17 \mathrm{e} / \mathrm{h}\end{array}$} & Column & $\begin{array}{l}\text { Dia. } \\
(\mathrm{mm})\end{array}$ & $\mathrm{V}_{\mathrm{up}}(\mathrm{m} / \mathrm{h})$ & Mass TSS (g) & $\%$ by Mass & $\begin{array}{l}\text { \% Retained } \\
\text { (Cumulative) }\end{array}$ \\
\hline & 1 & 63 & 3.98 & 9.83 & 30.37 & 30.37 \\
\hline & 2 & 75 & 2.82 & 16.20 & 50.06 & 80.43 \\
\hline & 3 & 90 & 1.73 & 4.08 & 12.60 & 93.03 \\
\hline & 4 & 110 & 1.16 & 2.00 & 6.17 & 99.20 \\
\hline & & Collection vessel & & 0.26 & 0.80 & \\
\hline \multicolumn{4}{|c|}{ Total mass recovered over the whole system $(\mathrm{g})$} & 32.36 & & \\
\hline \multicolumn{4}{|c|}{ Initial mass of the $1 \ell$ sludge sample $(\mathrm{g})$} & 31.94 & & \\
\hline \multicolumn{4}{|c|}{ Mass TSS recovered (\%) } & 101.3 & & \\
\hline
\end{tabular}

\section{R2 sludge sample}

Similarly, the sludge settleability profile for R2 sludge with respect to $\mathrm{V}_{\text {up }}$ was plotted (Fig. 6). At $\mathrm{Q}=7.08 \mathrm{\ell} / \mathrm{h}$, only $22 \%$ of the total sludge mass settled fast enough at a $\mathrm{V}_{\text {up }}$ as high as $2.8 \mathrm{~m} / \mathrm{h}$ while at $\mathrm{Q}=10.17 \mathrm{\ell} / \mathrm{h}$ an even smaller fraction $(\sim 9.7 \%)$ of the total sludge mass could settle at a $\mathrm{V}_{\text {up }}$ as high as 4.0 $\mathrm{m} / \mathrm{h}$. From the $10.17 \mathrm{\ell} / \mathrm{h}$ profile, it is observed that $31 \%$ of the total sludge mass settled fast enough at a $\mathrm{V}_{\text {up }}$ of $2.8 \mathrm{~m} / \mathrm{h}$ to be retained in Column $1(10 \%)$ and Column 2 (21\%) which is $10 \%$ more than retained in Column 1 at the same $\mathrm{V}_{\text {up }}$ of $2.8 \mathrm{~m} / \mathrm{h}$ at $7.08 \mathrm{l} / \mathrm{h}$.

From Table 2 or Fig. 7, 99\% of the total sludge mass was retained in the settleometer at a $\mathrm{V}_{\text {up }}>1.16 \mathrm{~m} / \mathrm{h}$ indicating that $\mathrm{R} 2$ sludge had good settling properties similar to the R1 sludge The maximum $\mathrm{V}_{\text {up }}$ at which $\mathrm{R} 2$ was operated was $0.085 \mathrm{~m} / \mathrm{h}$, which is 13 times lower than $1.16 \mathrm{~m} / \mathrm{h}$. Accordingly, it was concluded also for the R2 sludge that sludge settleability was not the cause of unstable conditions and therefore not the capacitylimiting process when both UASB reactors were operated at their respective minimum hydraulic retention times.

\section{Bed expansion ratio}

The HRT was reduced by increasing the feed flow rate: the higher the feed (and recycle) flow rate the greater the sludge bed expansion. When the reactors were operated at an HRT of lower than the minimum value (i.e. $13.5 \mathrm{~h}$ and $18 \mathrm{~h}$ for $\mathrm{R} 1$ when fed 1500 and $1800 \mathrm{mgSO}_{4}^{2-/ \ell}$ respectively, and $20.5 \mathrm{~h}$ for R2), the reactor sludge bed expanded above the pre-established bed height (corresponding to $6.7 \ell$ for $\mathrm{R} 1$ fed $1500 \mathrm{mgSO}_{4}^{2-/ \ell}$, $7.1 \ell$ for R1 fed $1800 \mathrm{mgSO}_{4}^{2-} / \ell$ and $7.4 \ell$ for R2). Since the bed volume was maintained at a constant volume, the mass of sludge removed from the system correspondingly increased, causing a reduced sludge bed mass (and biomass sludge age) and concomitantly a reduced biomass available to mediate the

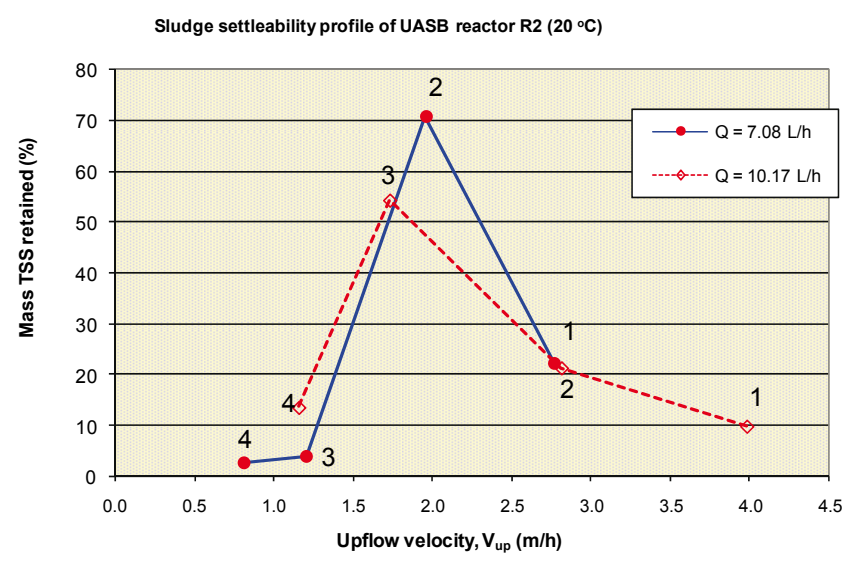

Figure 6

$R 2$ sludge settleability profile with respect to the two applied flow rates

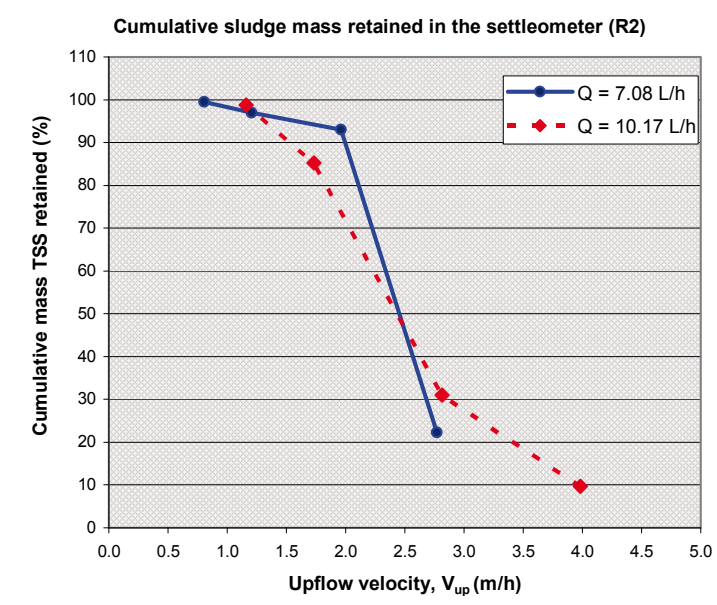

Figure 7

Percentage cumulative sludge mass retained with settling velocity (sludge from UASB reactor $R 2$ ) 


\begin{tabular}{|c|c|c|c|c|c|c|}
\hline \multicolumn{7}{|c|}{$\begin{array}{c}\text { TABLE } 2 \\
\text { Summary of results obtained with sludge from UASB reactor R2 }\end{array}$} \\
\hline \multicolumn{7}{|c|}{ R2 sludge } \\
\hline \multirow{6}{*}{$\begin{array}{l}\text { Applied flow rate, } \\
Q=7.08 \mathrm{e} / \mathrm{h}\end{array}$} & Column & $\begin{array}{l}\text { Dia. } \\
(\mathrm{mm})\end{array}$ & $\mathrm{V}_{\mathrm{up}}(\mathrm{m} / \mathrm{h})$ & Mass TSS (g) & $\%$ by Mass & $\begin{array}{l}\text { \% Retained } \\
\text { (cumulative) }\end{array}$ \\
\hline & 1 & 63 & 2.77 & 7.30 & 22.23 & 22.23 \\
\hline & 2 & 75 & 1.96 & 23.26 & 70.82 & 93.04 \\
\hline & 3 & 90 & 1.21 & 1.27 & 3.87 & 96.92 \\
\hline & 4 & 110 & 0.81 & 0.82 & 2.51 & 99.43 \\
\hline & & Collection vessel & & 0.19 & 0.57 & \\
\hline \multicolumn{4}{|c|}{ Total mass recovered over the system $(\mathrm{g})$} & 32.85 & & \\
\hline \multicolumn{4}{|c|}{ Initial mass of the $1 \ell$ sludge sample $(\mathrm{g})$} & 33.41 & & \\
\hline \multicolumn{4}{|c|}{ Mass TSS recovered (\%) } & 98.3 & & \\
\hline \multirow{6}{*}{$\begin{array}{l}\text { Applied flow rate, } \\
Q=10.17 \mathrm{e} / \mathrm{h}\end{array}$} & Column & $\begin{array}{l}\text { Dia. } \\
(\mathrm{mm})\end{array}$ & $V_{\text {up }}(m / h)$ & Mass TSS (g) & $\%$ by Mass & $\begin{array}{l}\text { \% Retained } \\
\text { (cumulative) }\end{array}$ \\
\hline & 1 & 63 & 3.98 & 3.11 & 9.73 & 9.73 \\
\hline & 2 & 75 & 2.82 & 6.78 & 21.24 & 30.96 \\
\hline & 3 & 90 & 1.73 & 17.34 & 54.30 & 85.26 \\
\hline & 4 & 110 & 1.16 & 4.29 & 13.44 & 98.71 \\
\hline & & Collection vessel & & 0.41 & 1.29 & \\
\hline \multicolumn{4}{|c|}{ Total mass recovered over the system $(\mathrm{g})$} & 31.94 & & \\
\hline \multicolumn{4}{|c|}{ Initial mass of the $1 \ell$ sludge sample $(\mathrm{g})$} & 31.45 & & \\
\hline \multicolumn{4}{|c|}{ Mass TSS recovered $(\%)$} & 101.6 & & \\
\hline
\end{tabular}

BSR reactions. As a result, sulphate and VFA concentrations accumulated in the reactor until such time that the system failed, indicated by a bed separation, sludge losses in the effluent and significant increase in the effluent TSS and organic COD concentrations.

Based on the above, the effect of bed expansion on the UASB reactor performance was investigated, both in the UASB reactor itself and in the second settleometer test at $10.17 \mathrm{1} / \ell$.

The bed expansion ratio is the bed volume (or height) at some upflow velocity over the bed volume (or height) when the upflow rate is zero.

$$
\begin{aligned}
& \text { Bed expansion ratio }(B E R)=\frac{\text { Bed volume at } V_{\text {up }}=0.127 \mathrm{~m} / \mathrm{h}}{\text { Bed volume at } V_{\text {up }}=0 \mathrm{~m} / \mathrm{h}} \\
& =\frac{6.7 \ell}{3.75 \ell}=1.8
\end{aligned}
$$

A typical example of sludge bed expansion when R1 was fed $1500 \mathrm{mgSO}_{4}{ }^{2-} / \ell$ at an HRT of $13.5 \mathrm{~h}$ is illustrated in Fig. 8. The BERs were 1.8 for R1 when fed both 1500 and $1800 \mathrm{mgSO}_{4}^{2-/ \ell}$ and 2.0 for R2.

The sludge content in each column of the settleometer for both R1 and R2 sludges was measured at their respective operating upflow velocity (Tables 1 and 2). In addition, the bed height for both $\mathrm{V}_{\text {up }}=0$ and the operating $\mathrm{V}_{\text {up }}$ were measured in the second test on the R1 and R2 sludges at the $10.17 \mathrm{\ell} / \mathrm{h}$ flow rate. Table 3 lists the BER results. The concentrations listed in Table 3 are the expanded bed TSS concentrations. If this concentration is multiplied by the upflow velocity, the flux in kgTSS/ $\left(\mathrm{m}^{2} \cdot \mathrm{h}\right)$ of the solids in the column is obtained, which are also listed in Table 3, as well as the corresponding results for R1 and R2 at the minimum HRT for stable operation. In Fig. 9 the BER vs. $V_{\text {up }}$ for the R1 and R2 sludges in the settleometer test and the 2 UASB reactors are shown. Also shown in Fig. 9 are the expanded bed concentrations and fluxes at the different $V_{\text {up }}$.

From Fig. 9, it can be seen that the BERs for the R2 sludge $\left(20^{\circ} \mathrm{C}\right)$ are higher than those of the $\mathrm{R} 1$ sludge $\left(35^{\circ} \mathrm{C}\right)$ at all

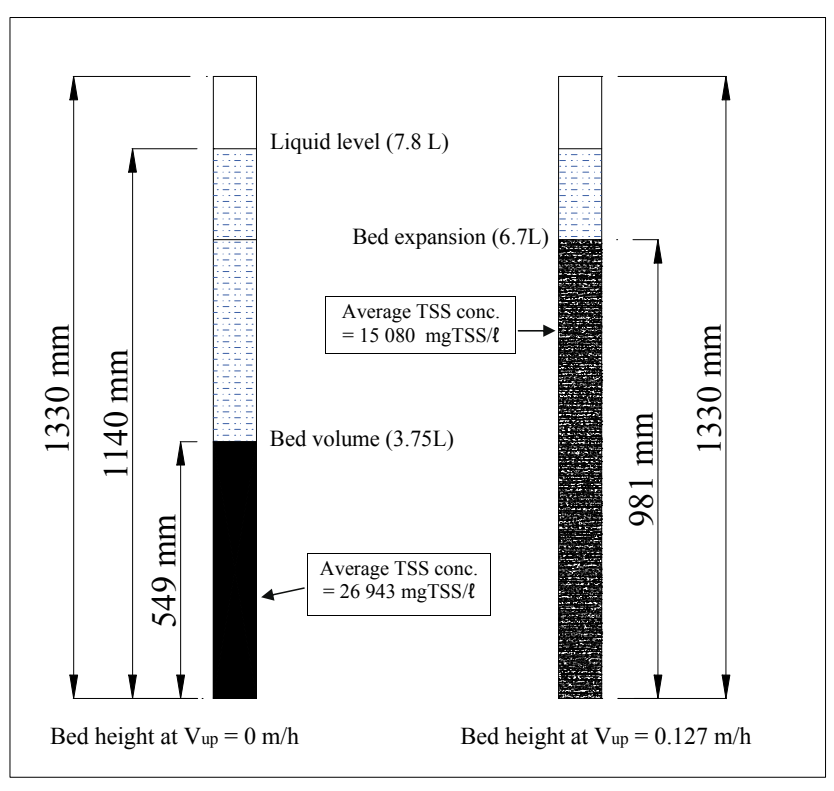

Figure 8

Illustration of R1 sludge bed expansion when operated with $1500 \mathrm{mgSO}_{4}{ }^{2-/ /}$ at an HRT of $13.5 \mathrm{~h}$

operating $\mathrm{V}_{\text {up }}$ values from 3.98 (Column 1) to $1.16 \mathrm{~m} / \mathrm{h}$ (Column 4). The BER of the R2 sludge is arund 2.0 in Columns 1 to 3 as the expanded bed concentration increases from 2.43 to 5.91 gTSS/ $\ell$ and $V_{\text {up }}$ decreases from 3.98 to $1.73 \mathrm{~m} / \mathrm{h}$ in Columns 1 , 2 and 3 respectively. Interestingly, the flux, or product of the expanded bed concentration and settling velocity, of the solids retained in Columns 1 to 3 remains approximately constant at around $10 \mathrm{kgTSS} /\left(\mathrm{m}^{2} \cdot \mathrm{h}\right)$ at the BER of 2.0. Only in Column 4 at the lowest $\mathrm{V}_{\text {in }}(1.16 \mathrm{~m} / \mathrm{h})$ is the concentration and flux very low at $0.46 \mathrm{gTSS} / \ell$ and $1.14 \mathrm{kgTSS} /\left(\mathrm{m}^{2} \cdot \mathrm{h}\right)$ respectively. For the R1 sludge, the BERs are somewhat lower (1.8). However, 
TABLE 3

Relationship between bed expansion and upflow velocity for both R1 and R2 sludges

\begin{tabular}{|c|c|c|c|c|c|c|c|c|c|c|}
\hline & \multicolumn{2}{|c|}{ Column 1} & \multicolumn{2}{|c|}{ Column 2} & \multicolumn{2}{|c|}{ Column 3} & \multicolumn{2}{|c|}{ Column 4} & \multicolumn{2}{|c|}{ UASB $^{1}$} \\
\hline & R1 & $\mathbf{R 2}$ & R1 & $\mathbf{R 2}$ & R1 & $\mathbf{R 2}$ & R1 & $\mathbf{R 2}$ & R1 & $\mathbf{R 2}$ \\
\hline Sludge conc ${ }^{2}(\mathrm{gTSS} / \ell)$ & 7.70 & 2.43 & 8.97 & 3.76 & 1.39 & 5.91 & 0.456 & 0.98 & 15.08 & 12.61 \\
\hline Upflow velocity $\left(\mathrm{V}_{u p}, \mathrm{~m} / \mathrm{h}\right)$ & \multicolumn{2}{|c|}{3.98} & \multicolumn{2}{|c|}{2.82} & \multicolumn{2}{|c|}{1.73} & \multicolumn{2}{|c|}{1.16} & 0.127 & 0.085 \\
\hline Bed height at $\mathrm{V}_{\mathrm{un}}(\mathrm{mm})$ & 89.0 & 42.7 & 109.6 & 75.3 & 20.5 & 138.2 & 7.5 & 14.0 & 981 & 1083 \\
\hline Bed height at $V_{\text {up }}=0(\mathrm{~mm})$ & 52.5 & 21.5 & 64.5 & 38.6 & 19 & 68.1 & 7.2 & 10.7 & 549 & 541 \\
\hline Bed expansion (mm) & 36.7 & 21.2 & 45.1 & 36.7 & 1.5 & 70.1 & 0.3 & 3.2 & 432 & 542 \\
\hline Bed expansion ratio (BER) & 1.71 & 1.99 & 1.73 & 1.95 & 1.08 & 2.03 & 1.05 & 1.30 & 1.78 & 2.0 \\
\hline Flux $^{3}\left[\mathrm{kgTSS} /\left(\mathrm{m}^{2} \cdot \mathrm{h}\right)\right]$ & 30.6 & 9.7 & 25.3 & 10.6 & 2.4 & 10.2 & 0.53 & 1.14 & 1.92 & 1.07 \\
\hline
\end{tabular}

At minimum HRT for stable operation

${ }^{2}$ Average concentration of the expanded bed

${ }^{3}$ Flux is the product of the expanded bed concentration and upflow velocity

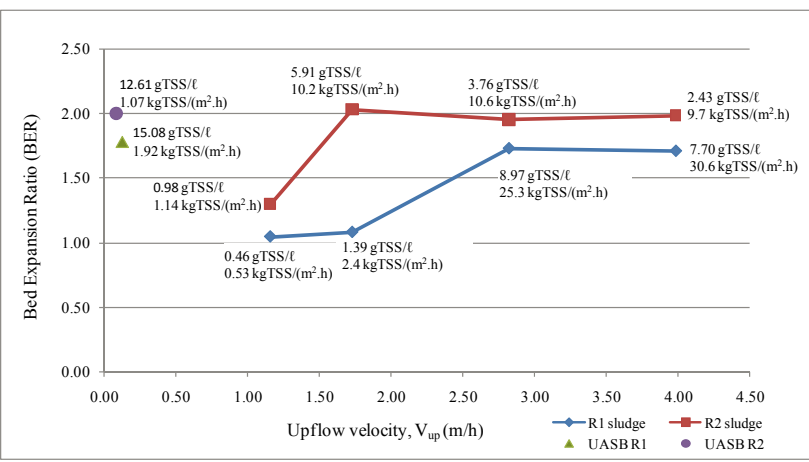

Figure 9

Bed expansion ratio (BER) versus upflow velocity $\left(V_{\text {up }}\right)$ for $R 1$ and $R 2$ sludges. The expanded bed concentrations and solids fluxes in each column of the settleometer and UASB reactors are also shown.

the concentrations and fluxes are much higher in the first two columns ( 1 and 2 ) than those of the first two columns of the R2 sludge - the concentrations are 7.70 and $8.97 \mathrm{gTSS} / \ell$ and the fluxes 30.6 and $25.3 \mathrm{kgTSS} /\left(\mathrm{m}^{2} \cdot \mathrm{h}\right)$, more than two times those in the first two columns of the R2 sludge. For the R1 sludge retained in Columns 3 and 4 at $\mathrm{V}_{\text {up }}$ of 1.73 and $1.16 \mathrm{~m} / \mathrm{h}$, the $\mathrm{BER}$, expanded bed concentrations and fluxes decrease sharply to $1.08,1.39 \mathrm{gTSS} / \ell$ and $2.4 \mathrm{kgTSS} /\left(\mathrm{m}^{2} \cdot \mathrm{h}\right)$ in Column 3 and $1.05,0.46 \mathrm{gTSS} / \ell$ and $0.53 \mathrm{kgTSS} /\left(\mathrm{m}^{2} \cdot \mathrm{h}\right)$ in Column 4.

The hydraulic conditions in the R1 and R2 UASB reactors are also given in Table 3 and shown in Fig. 9. While the BERs are similar ( 1.7) in the R1 UASB reactor and Columns 1 and 2 of the R1 settleometer test, the UASB R1 expanded bed concentration is much higher (about double, $\sim 15.1 \mathrm{vs} \sim 8 \mathrm{gTSS} / \ell$ ) and the fluxes much lower $\left(\sim 2 \mathrm{vs} \sim 30 \mathrm{kgTSS} /\left(\mathrm{m}^{2} \cdot \mathrm{h}\right)\right)$ than Columns 1 and 2. This is probably due to the much lower upflow velocity in the R1 UASB reactor compared with those in the settleometer test less than $1 / 10^{\text {th }}$ of $\mathrm{V}_{\text {up }}$ in Column 4 (slowest) and $1 / 30^{\text {th }}$ of $\mathrm{V}_{\text {up }}$ in Column 1 (fastest). Similarly, the BERs in the R2 UASB reactor and Columns 1, 2 and 3 of the R 2 settleometer test are closely the same $(\sim 2)$, but the UASB R2 expanded bed concentration is much higher (about double, $\sim 12.61$ vs $\sim 6 \mathrm{gTSS} / \ell$ ) and the fluxes much lower ( $\left.\sim 1 \mathrm{vs} \sim 10 \mathrm{kgTSS} /\left(\mathrm{m}^{2} \cdot \mathrm{h}\right)\right)$ than Columns 1,2 an 3 . As for the R1 UASB reactor, the upflow velocity in the R2 UASB reactor also is much lower compared with those in the settleometer test - less than $1 / 10^{\text {th }}$ of $\mathrm{V}_{\text {up }}$ in Column 4 (slowest) and $1 / 30^{\text {th }}$ of $\mathrm{V}_{\text {up }}$ in Column 1 (fastest).

The settleometer test fractionated the R1 sludge into four parts with different settling velocities, expanded bed concentrations and fluxes, i.e. Column 1 solids with a settling velocity
$>4.0 \mathrm{~m} / \mathrm{h}$, concentration $=7.70 \mathrm{gTSS} / \ell$ and flux $30.6>\mathrm{kgTSS} /$ $\left(\mathrm{m}^{2} \cdot \mathrm{h}\right)$, Column 2 solids with a settling velocity $>2.8 \mathrm{~m} / \mathrm{h}$, concentration $=8.97 \mathrm{gTSS} / \ell$ and flux $>25.3 \mathrm{kgTSS} /\left(\mathrm{m}^{2} \cdot \mathrm{h}\right)$, Column 3 solids with a settling velocity $>1.73 \mathrm{~m} / \mathrm{h}$ concentration $=1.39$ $\mathrm{gTSS} / \ell$ and flux $>2.4 \mathrm{kgTSS} /\left(\mathrm{m}^{2} \cdot \mathrm{h}\right)$ and Column 4 solids with a settling velocity $>1.16 \mathrm{~m} / \mathrm{h}$ concentration $=0.46 \mathrm{gTSS} / \ell$ and flux $>0.53 \mathrm{kgTSS} /\left(\mathrm{m}^{2} \cdot \mathrm{h}\right)$. This fractionation did not appear to take place in the R1 and R2 UASB reactors. The concentration depth profiles indicated that apart from a high concentration at the bottom of the reactor, the expanded bed concentration was quite uniform with depth (Part 3, Poinapen et al., 2009). The sludge bed in the UASB reactor was therefore quite uniform, probably due to the very low upflow velocity compared with the settling velocity of all the solids. The uniform sludge bed concentration in the UASB reactor was also contributed by the sludge recycle from the top to the bottom of the reactor bed to enhance sulphate reduction as soon as the feed enters the UASB reactor.

None of the expanded bed concentrations in the settleometer were as high as in the UASB reactors, but also none of the upflow velocities in the UASB reactors were as high as the slowest in the settleometer tests (only $1 / 10^{\text {th }}$ ). This means that all the solids in the UASB reactor settled faster than the slowest $\mathrm{V}_{\text {up }}$ in the settleometer test $(1.16 \mathrm{~m} / \mathrm{h})$. Clearly bed expansion fixes the reactor height rather than the settling velocity of the sludge.

For maximum reactor substrate loading rates (with a fixed feed PSS and sulphate concentration), the feed flow rate was increased to its maximum value for stable bed operation and effluent quality (VFA $<50 \mathrm{mgHAc} / \ell$ and sulphate $<250 \mathrm{mgSO}_{4}^{2-/ \ell}$ ). This increase in feed flow rate increases the upflow velocity $\left(\mathrm{V}_{\text {up }}\right)$, which causes the sludge bed to expand. Additionally, the reactor was operated with a recycle at half the feed flow rate from the top to the bottom of the sludge bed, which further expanded the bed. While the results obtained from the laboratory UASB reactors and settleometer tests give some insight into the sludge settling velocity, bed expansion ratio, expanded bed solids concentration, flux and sludge age, the relationship between bed expansion, solids concentration, upflow velocity and sludge age may be different for different primary sludges and will need to be determined on site. It is therefore important to build sufficient flexibility into the design to deal with different bed expansion ratios, upflow velocities and sludge ages.

\section{Conclusions}

A settling device (settleometer) was designed and built to test the settleability of two sludges taken from two UASB reactors ( $\mathrm{R} 1$ and $\mathrm{R} 2$ ) operated at $35^{\circ} \mathrm{C}$ and $20^{\circ} \mathrm{C}$ respectively to 
investigate whether sludge settleability or bed expansion in a UASB BSR reactor (fed PSS as carbon source) is the capacity limiting process of the system

It was concluded that both R1 and R2 sludges settled well. At upflow velocities below $1.16 \mathrm{~m} / \mathrm{h}, 99 \%$ of the total sludge mass was retained. This upflow velocity was 9.1 and 13.7 times higher than the maximum operating upflow velocity of R1 $(0.127 \mathrm{~m} / \mathrm{h})$ and R2 $(0.085 \mathrm{~m} / \mathrm{h})$ that caused system failure (high effluent volatile fatty acids and sulphate). Because the sludge settling velocity was more than 10 times faster than the maximum upflow velocity, tests were also done to demonstrate the effect of upflow velocity on the sludge bed expansion. It was found that R1 and R2 sludges had bed expansion ratios of 1.8 at $\mathrm{V}_{\text {up }}$ of $0.127 \mathrm{~m} / \mathrm{h}$ and 2.0 at $\mathrm{V}_{\text {up }} 0.085 \mathrm{~m} / \mathrm{h}$ respectively. Since the UASB systems were operated with a constant bed volume, the mass of sludge removed from the system increases with increasing upflow rate, causing a reduced sludge bed mass and concomitantly a reduced biomass available to mediate the reactions. The cause for the progressive system failure at an upflow velocity higher than the maximum was therefore due to the sludge bed expansion rather than the sludge settleability problems. In addition, from the sludge settleability and bed expansion tests, it was deduced that R1 sludge $\left(35^{\circ} \mathrm{C}\right)$ had a better settleability and expanded less compared to R2 sludge $\left(20^{\circ} \mathrm{C}\right)$ at the same upflow velocity. Hence, this explains the shorter minimum HRT (13.5 h) obtained in R1 compared with that $(20.5 \mathrm{~h})$ of $\mathrm{R} 2$ for the same feed sulphate of 1500 $\mathrm{mgSO}_{4}^{2-/ \ell}$.

\section{Acknowledgements}

This research was supported financially by the Water Research Commission, the National Research Foundation and the University of Cape Town and is published with their permission.

\section{References}

MOOSBRUGGER RE (1994) Settleability assessment of granular biomass from upflow anaerobic sludge bed reactors. AD94, Proc. $7^{\text {th }}$ Int. Symp. on Anaerobic Digestion. 23-27 January, Cape Town, South Africa. Poster reprints. 215-218.

POINAPEN J, EKAMA GA and WENTZEL MC (2009) Biological sulphate reduction with primary sewage sludge in an upflow anaerobic sludge bed (UASB) reactor - Part 3: Performance at $20^{\circ} \mathrm{C}$ and $35^{\circ} \mathrm{C}$. Water $S A 35$ (5) 543-552.

STANDARD METHODS (1985) Standard Methods for the Examination of Water and Wastewater (19 ${ }^{\text {th }}$ edn.). American Public Health Association/American Water Works Association/Water Environment Federation (APHA/AWWA/WEF), Washington DC, USA. 
Available on website http://www.wrc.org.za ISSN 0378-4738 (Print) = Water SA Vol. 35 No. 5 October 2009 ISSN 1816-7950 (On-line) $=$ Water SA Vol. 35 No. 5 October 2009 